УДК 373.3:51

DOI:

Олег Довгий, кандидат фізико-математичних наук, доиент, доиент кафедри педагогіки початкової освіти Прикарпатського наџіонального університету імені Василя Стефаника

\title{
ФОРМУВАННЯ МАТЕМАТИЧНОЇ КОМПЕТЕНТНОСТІ УЧНІВ ПОЧАТКОВОЇ ШКОЛИ ЯК ПЕДАГОГІЧНА ТА ОСВІТНЯ ПРОБЛЕМА
}

Стаття присвячена проблемі формування математичної компетентності учнів початкової школи. У міжнародних рекомендаціях (за даними тестувань PIZA, TIMSS, PIRLS) наголошено на необхідності підвищити якість математичної освіти, навчати школярів застосовувати знання у життєвих ситуаціях. У зв'язку з ичим формування математичної компетентності необхідно здійснювати з периого року навчання дитини в школі. Не випадково 2020-2021 навчальний рік в Украйні оголотено Роком математичної освіти. Перед початковою школою стоїть завдання - створити всі умови для розвивального навчання, що модернізує зміст початкової математичної освіти. Зроблено висновок, що виникнення інтересу до математики в учнів початкових класів, щзо є чинником формування їхньої математичної компетентності, залежить і від методики іï викладання.

Ключові слова: математична компетентність; інтерес до математики; учні початкової школи; математичні завдання; розвивальне навчання.

Jim. 11.

Oleh Dovhiy, Ph.D.(Physical and Mathematical), Associate Professor of the Primary Education Pedagogy Department Vasyl Stefanyk Precarpathian National University

\section{FORMATION OF MATHEMATICAL COMPETENCE OF PRIMARY SCHOOL STUDENTS AS A PEDAGOGICALAND EDUCATIONAL ISSUE}

The article is devoted to the issue of formation of mathematical competence of primary school students. International recommendations (according to PIZA, TIMSS, and PIRLS tests) emphasize the need to improve the quality of mathematics education, to teach students how to apply knowledge in life situations. Therefore, the formation of mathematical competence should be carried out from the first year of the child's schooling. The 2020 2021 academic years in Ukraine was declared the Year of Mathematical Education. The task of primary school is to create all the conditions for developmental learning, which modernizes the content of primary mathematics education. This will promote mathematical development of primary school children, organization of mathematics teaching on the principles of humanization, continuity, universal and national values, the needs of general cultural development of students, and enrich the content of mathematical training of students with motivational, educational and developmental material. Mathematics lessons should include tasks that are aimed at formation of key and subject (mathematical) competencies of each primary school student. It is necessary to help young students to understand the role of mathematics in cognition of reality and the practical life of humans. Students must be able to solve situational problems, reason logically, justify their actions and perform them according to the algorithm, use mathematical terminology, sign and graphic information, be familiar with plane and space, apply computing skills in practical situations, and so on. The emergence of interest in mathematics among primary school students depends on the methods of its teaching. This is served by such methodological methods of developmental learning as creating a situational problem in teaching mathematics, using life phenomena, facts, interesting historical material (facts of biography of mathematicians, mathematical tricks, logic problems, didactic games, etc.), research and creative tasks (creating mathematical crossword puzzles and projects, writing essays, drawing illustrations, etc.).

Keywords: mathematical competence; interest in mathematics; primary school students; mathematical problems; developmental learning.

П остановка проблеми. Високий рівень володіння математичною компетентністю є показником якості освітинаміжнародномурівнітаконкурентоспроможності країни в галузі фундаментальних наук та новітніх технологій. У міжнародних рекомендаціях (за даними тестувань PIZA, TIMSS, PIRLS) наголошується на необхідності приділяти більше уваги практичній стороні природничоматематичної освіти, навчати школярів застосовувати знання у життєвих ситуаціях, посилення уваги до загального розвитку учнів засобами природничо-математичної освіти [10].

Важлива роль математики в житті сучасної людини зумовлена необхідністю використання розрахунків та складання алгоритмів у процесі 


\section{ФОРМУВАННЯ МАТЕМАТИЧНОЇ КОМПЕТЕНТНОСТІ УЧНІВ ПОЧАТКОВОЇ ШКОЛИ ЯК ПЕДАГОГІЧНА ТА ОСВІТНЯПРОБЛЕМА}

розв'язання більшості життєвих проблем. У зв'язку 3 цим формування математичної компетентності необхідно здійснювати з першого року навчання дитини в школі. Не випадково 2020-2021 навчальний рік в Україні, як відомо, оголошено Роком математичної освіти [9], про що було анонсовано ще грудні 2019 р. під час презентації Національного та Міжнародного звітів за результатами міжнародного дослідження якості освіти PISA-2018, яке показало, що 36 \% 15 річних учнів не досягають базового рівня знання 3 математики [11]. Тому однією 3 ініціатив, покликаних розв'язати цю проблему, стало оголошення навчального року 2020-2021 Роком математичної освіти, що передбачає проведення заходів, покликаних забезпечити рівний доступ учнів до вивчення математики і застосування сучасних технологій навчання математики, удосконалити ресурсне забезпечення освітнього процесу, підвищити мотивацію школярів до вивчення математики та іiї застосування у житті, популяризувати математичну освіту. Йдеться не тільки про збільшення кількості навчальних годин на вивчення математики в Державному стандарті базової середньої освіти, а й упровадження курсів “Логіка", "Математична логіка" до варіативного складника навчальних планів 1-11 класів, проведення тренінгів для вчителів початкових класів та вихователів закладів дошкільної освіти, застосовуючи легоматематику в освітньому процесі, розширення мережі математичних гуртків у закладах загальної середньої та позашкільної освіти, організацію літніх “математичних шкіл” для вчителів та учнів, популяризацію математичної освіти тощо [9]

Обов'язкова державна підсумкова атестація у формі ЗНО з математики спонукає, окрім іншого, і до забезпечення якісного вивчення математики в школі, спрямовує на формування математичної компетентності учнів. На це орієнтує і Концепція “Нова українська школа”, де викладені ключові компетентності, що визначені "Рекомендаціями Європейського парламенту та Ради Європи щодо формування ключових компетентностей освіти впродовж життя", зпоміж яких - математична, що передбачає виявлення простих математичних залежностей у навколишньому світі, моделювання процесів та ситуацій із застосуванням математичних відношень і вимірювань, усвідомлення ролі математичних знань та вмінь в особистому й суспільному житті людини, а також формування умінь лаконічно, зрозуміло формулювати думку, аргументувати, доводити правильність тверджень тощо [7].
Аналіз останніх досліджень і публікацій. Науковці активно досліджують різні аспекти проблеми математичної компетентності учнів. Так, упрацях М. Богдановича, Н. Будної, Л. Зайцевої, Л. Коваль, Я. Король, О. Корчевської, С. Краснякова, В. Кушнір, І. Осадчого, С. Ракова, І. Романишин, Р. Романишин, С. Скворцової, Л. Черкаської, Т. Чернецької, В. Швеця та інших учених розглядаються особливості навчання математики в початковій школі, питання ефективності активізації учнів на уроках математики, прикладної спрямованості шкільного курсу математики, формування і розвиток логікоматематичних здібностей тощо.

Мета статті - схарактеризувати окремі засоби формування математичної компетентності молодших школярів.

Виклад основного матеріалу. У міжнародному досвіді усталилося розуміння компетентності як інтегрованого результату освіти, присвоєного особистістю; нині у світовій практиці ефективність освіти пов'язується з реалізацією компетентнісного підходу. Компетентнісні результати навчання учнів початкової школи визначено в ключових освітніх документах (Державному стандарті [3], у вимогах навчальних програм [6] тощо). Проте перехід на компетентнісні засади що належним чином не відображено в дидактичному й методичному забезпеченні навчання математики в початковій школі, де і надалі домінує знаннєва компонента (стандарт 2011 р. здебільшого орієнтував учителів початкових класів на формування в учнів предметних компетентностей, тоді як чинні нормативи, зокрема й Концепція НУШ, спрямовані на досягнення ще й ключових).

Як слушно зауважують українські науковці [2; $5 ; 8 ; 10]$, зокрема авторитетна вчена С. Скворцова, потрібно актуалізувати розвивальне навчання, що модернізує зміст початкової математичної освіти, активізує математичний розвиток молодших школярів, сприяє організації навчання математики на принципах гуманізації, цілісності, наступності, загальнолюдських і національних цінностей, потреб загальнокультурного розвитку учнів, збагачує зміст математичної підготовки школярів мотиваційним, виховним i розвивальним матеріалом, а також забезпечує впровадження інноваційних технологій, що уможливлюють технологізацію змісту та процесу навчання математики учнів початкової школи тощо. Звідси окреслюється завдання такої побудови підручників математики таким чином, щоб вони включали завдання, які спрямовані на формування ключових та предметних (математичних) 


\section{ФОРМУВАННЯ МАТЕМАТИЧНОЇ КОМПЕТЕНТНОСТІ УЧНІВ ПОЧАТКОВОЇ ШКОЛИ}

ЯК ПЕДАГОГІЧНА ТА ОСВІТНЯ ПРОБЛЕМА

компетентностей кожного випускника початкової школи, слугували інтеграції як провідному принципу навчання та реалізації змісту, де інваріантним складником є засвоєння знань про цілісність світу, взаємозв'язок між різними математичними явищами, властивостями, здобуття індивідуального досвіду, розв'язання різних типів навчальних (сюжетних) і життєвих завдань, з-поміж яких є обов'язковими є творчі та 3 логічним навантаженням [5, 15].

Задля досягнення цієї мети, окрім іншого, передбачено формування у молодших школярів розуміння ролі математики в пізнанні дійсності; готовності до розпізнавання проблем, які розв'язуються із застосуванням математичних методів, здатності розв'язувати сюжетні задачі, логічно міркувати, обгрунтовувати свої дії та виконувати дії за алгоритмом; уміння користуватися математичною термінологією, знаковою і графічною інформацією; орієнтуватися на площині та в просторі, застосовувати обчислювальні навички в практичних ситуаціях і розуміти сутність процесу вимірювання величин тощо [3]. В освітній галузі "Математика" цьому слугують такі змістові лінії: числа, дії із числами; величини; математичні вирази, рівності, нерівності; сюжетні задачі; просторові відношення, геометричні фігури; робота з даними. В основі змісту базової навчальної програми 3 початкового курсу математики [1] - формування початкових математичних знань і способів діяльності, їх практичне застосування спрямовується на засвоєних учнями в передшкільний період математичних уявленнях, які на елементарному рівні відображають ознаки, властивості та відношення предметів навколишнього світу. Отже, одне із ключових завдань навчання математики в початковій школі - формування в учнів усвідомлених і міцних обчислювальних навичок, що становлять основу обчислювальної компетентності [1].

Утім, як показує практика, сьогодні існує проблема втрати пізнавального інтересу учнів до навчання математики, як наслідок, відбувається погіршення успішності здобувачів освіти [4]. Розглянемо окремі засоби формування у молодших школярів пізнавальних інтересів до математики. До групи стимулів можна віднести новизну змісту навчального матеріалу 3 математики, практичне значення змісту математичних знань, історизм та сучасні здобутки математичної науки тощо. Так, до прикладу, інтерес до вивчення того чи іншого математичного питання залежить від переконаності учня в необхідності цього. Найбільш успішно попередня мотивація реалізується через звернення до практики. Тому доречним буде почати виклад нового теоретичного матеріалу 3 прикладних завдань, що порушують питання, які розглядаються. Так, вивчення теми "Рівняння" можна почати з демонстрації малюнка до такого орієнтовного завдання: "На лівій чаші терезів лежать кавун та гиря в 3 кг, відповідно на правій - гиря в 6 кг. Терези перебувають у рівновазі. Чому дорівнює маса кавуна?”. До сприйняття поняття “найбільший спільний дільник” можна спочатку запропонувати таке завдання: “Яку найбільшу кількість подарунків до свята Миколая можна зробити із 48 мандаринок та 36 бананів, якщо треба використовувати всі фрукти?”.

Отже, під час вивчення школярами нового матеріалу варто розкрити його практичну значущість, наголосити на міжпредметних зв'язках математики, увиразнити важливість математичних знань, до прикладу, для визначення положення небесних світил, складання карти зоряного неба, передбачення сонячних затемнень, розрахунків траєкторій комет тощо, а це слугуватиме тому, що учні поступово позбавляться від стереотипних уявлень про математику як “суху науку”, відірвану від життя та навколишнього світу. Великий емоційноестетичний вплив на учнів мають демонстрування репродукцій архітектурних споруд доби Стародавнього Сходу, Античності, Відродження, Нового часу, нерукотворних об'єктів природи, листочків рослин, будови тварин, квітів тощо та розповіді про золотий переріз (перетин), його застосування в математиці, геометрії, живописі, скульптурі, архітектурі, музиці, велику увагу цьому поняттю, що уособлює “божественну пропорцію”, приділяв Леонардо да Вінчі та інші вчені. Такого характеру розповіді підкреслюють значення математичних знань, які лежать в основі універсального закону, у якому зафіксований основний принцип формотвірних прагнень до прекрасного й довершеного не тільки у сфері природи, але й мистецтва, що дає підстави стверджувати: математика - це не тільки струнка система чисел, теорем, завдань тощо, а й унікальний засіб пізнання краси, гармонії, природи. Вивчаючи деякі теми, учні за допомогою вчителя самі увиразнюють практичне значення вивчення математики, iї застосування у житті (на запитання “Де застосовуються відсотки?” учні зазвичай відповідають: "У банківській справі”, “У науці”, “В економіці”, “У промисловості”, “У сільському господарстві” та ін.).

Як показали результати контент-аналізу підручників з математики для початкової школи, 


\section{ФОРМУВАННЯ МАТЕМАТИЧНОЇ КОМПЕТЕНТНОСТІ УЧНІВ ПОЧАТКОВОЇ ШКОЛИ ЯК ПЕДАГОГІЧНА ТА ОСВІТНЯПРОБЛЕМА}

чимало математичних завдань мають нецікаві тексти, що не несуть жодної інформації, не відзначаються пізнавальним характером, часто в учнів такі задачі викликають байдужість до математики, апатію до здобуття знань, швидку втому, а внаслідок цього з'являється втрата інтересу до розв'язування завдань (учені підрахували, що діти під час навчання у школі розв'язують понад 20000 завдань). Цілком імовірно, що однією з причин нелюбові дітей до математичних завдань $\epsilon$ відсутність у задачах пізнавальної життєвої інформації. Тому для прищеплення інтересу до завдань та формування пізнавальної активності учнів на уроках математики доцільно використовувати завдання 3 літературними, історичними, біологічним, економічними, господарськими, побутовими, географічними сюжетами, для молодших школярів неодмінно треба застосовувати завдання 3 казковим сюжетом.

Виникнення інтересу до математики у значної частини учнів початкових класів залежить переважно від методики її викладання, від того, наскільки вміло буде організована навчальна робота $[2 ; 4 ; 5]$. Тому вчителеві треба дбати про те, щоб на уроках кожен учень працював активно, захоплено, і використовувати це як відправну точку виникнення та розвитку допитливості, глибокого пізнавального інтересу до математичних знань. Саме в період початкової математичної освіти педагогові потрібно прагнути розкрити привабливі сторони математики. Винятково важлива роль у цьому процесі належить дидактичним іграм. Сьогодні вчені слушно кваліфікують дидактичну гру як визнаний метод навчання і виховання, що володіє освітньою, розвивальною та виховною функціями, що діють в органічній єдності. Отже, дидактичні ігри доцільно широко використовувати й на уроках математики. До прикладу, ігри-загадки. Загадки створювалися самим українським народом, у них - віковий досвід, мудрість українства, вони входили в обряди, ритуали, включалися до свят, слугували народнопедагогічним засобом навчання і виховання, застосовувалися для перевірки знань, винахідливості. У цьому, власне, і полягає очевидна педагогічна спрямованість та популярність загадок як розумної розваги. За сучасного розвитку НУШ загадки, загадування та відгадування розглядаються як вид навчальної гри. Основною ознакою загадки є хитромудрий опис, який потрібно розшифрувати (відгадати та довести), а ключовою особливістю загадок $\epsilon$ логічне завдання. Способи побудови логічних завдань різні, але вони активізують розумову діяльність дитини. Дітям подобаються ігризагадки. Необхідність порівнювати, пригадувати, думати, здогадуватися - усе це приносить радість розумової праці. Розгадування загадок розвиває здатність до аналізу, узагальнення, формує вміння розмірковувати, робити висновки. Уміле використання народної творчості дає змогу змінити характер уроку, зацікавити учнів роботою. Ідеться, до прикладу, про народні задачі (загадки, прислів'я, небилиці, які містять математичні поняття). У них виявляється розум, кмітливість, спостережливість українського народу, відображено його життя. Наприклад: “Ішло 7 старців, несли по 7 ціпків, на кожному ціпку по 7 мішків, у кожному мішку по 7 кішок, у кожної кішки по 7 кошенят. Скільки всіх кошенят?". “Стоїть стовп, а на тому стовпі сорок кілець, до кожного кільця прив `язано по 40 кобил, у кожної кобили по 40 лошат. Скільки всього лошат?”. “Летіли гуси, а на зустріч їм один гусак. “Здраствуйте, 100 гусей”, - каже він. Йому відповідають: “А нас не сто. Щоб було сто, треба ще стільки та півстільки та чверть стільки і ти один”. Скільки летіло гусей?” Такі задачі можна пропонувати учням початкових класів при розв'язанні прикладів на всі дії.

Для розвитку логіко-математичних умінь учнів першого класу доречно запропонувати логічні задачі-жарти. Такі завдання потребують уваги, розвивають оригінальність мислення, винахідливість, допомагають школярам під час таких логікоматематичних п'ятихвилинок переключити увагу, відпочити, отримати позитивні емоції. До прикладу: Одне яйце можна зварити за сім хвилин. За скільки хвилин можна зварити три таких яйця? (За п’ять хвилин); Ти - капітан корабля далекого плавання, який прямує від Нью-Йорка до Барселони. Скільки років пілотові? (Оскільки пілот за умовою задачі - це учень, що розв'язує іiі, то відповіддю буде вік самого учня); У вазі було 20 троянд. На Свято матері ти подарував мамі, двом бабусям, сестрі по п’ять троянд і п’ять троянд залишилось у вазі. Як таке могло трапитися? (учень подарував комусь п’ять троянд, не витягаючи їх з вази).

Перед розв’язуванням задач доречно використати “загадкову розминку”. До прикладу: "Математику вивчаймо. Фрукти ми не забуваймо: Дуже жовті, апетитні, Наче сонечка, привітні. Зовсім не такі, як суші, А смачнезні наші .... (груші)”. А далі запропонувати учням умову задачі: в Оксанки було 56 груш. Четверту частину вона віддала Сергійкові, а другу частину від того, що залишилося, Андрійкові. Після цього вона додала Сергійкові ще одну свою грушу і попросила 


\section{ФОРМУВАННЯ МАТЕМАТИЧНОЇ КОМПЕТЕНТНОСТІ УЧНІВ ПОЧАТКОВОЇ ШКОЛИ ЯК ПЕДАГОГІЧНА ТА ОСВІТНЯПРОБЛЕМА}

Андрійка передати Сергійкові декілька груш. У результаті груш у хлопців стало порівну. Скільки груш Андрійко передав Сергійкові і по скільки груш стало в дітей?

Стимулювальний вплив на формування пізнавального інтересу до математики мають творчі роботи учнів. Вони активізують емоційновольові та інтелектуальні психічні процеси, сприяють формуванню творчих здібностей, математичної грамотності тощо. Складання математичних кросвордів - одне $з$ улюблених завдань школярів. У такий спосіб вони засвоюють математичну термінологію, навчаються формулювати питання, знаходити на них відповіді. Такий же навчальний ефект має створення дітьми казок, героями яких є числа чи геометричні фігури, та написання математичних творів / есе, присвячених розкриттю зв'язку математичних понять, що вивчаються, 3 навколишнім світом, практикою (“Навіщо мені потрібна математика?”, “Математика в професії моїх батьків", “Математика і бізнес" та ін.), створення малюнків чи аплікацій до окремих тем курсу математики (під час вивчення геометричних фігур можна запропонувати дітям завдання намалювати предмети, що оточують їх у повсякденному житті, мають форми вивчених на уроці тіл) та ін. Такі завдання дають змогу встановити зв'язок математики 3 довкіллям, увиразнити практичне значення цієї науки.

Висновки та перспективи подальших досліджень. Для того, щоб школярі стали активними учасниками процесу навчання математики в початковій школі, необхідно так організувати освітню діяльність, щоб учням було цікаво набувати нових знань, умінь та навичок. Виникнення інтересу молодших школярів до математики залежить від уміння вчителя створити ситуацію розвивального проблемного навчання, тобто таке життєве чи навчальне утруднення, що виникає тоді, коли учень розуміє завдання (явище, ситуацію), намагається $\dddot{1}$ розв'язати (пояснити), але йому бракує знань. Ця ситуація викликає в учнів бажання знайти пояснення незрозумілому факту, створює мотиви навчальної діяльності. Цьому слугують такі методичні прийоми, як створення проблемної ситуації в навчанні математики, використання життєвих явищ, фактів, їх аналіз із метою теоретичного пояснення, а також завдань міжпредметного, прикладного, професійного характеру, застосування історичного чи цікавого матеріалу (фактів біографії математиків, математичних фокусів, логічних завдань, дидактичних ігор тощо), організація практичної роботи дослідницького та творчого характеру, у ході якої учні доходять емпіричних висновків, що потребують теоретичного обгрунтування. Стимулювальний вплив на формування пізнавального інтересу до математики мають творчі роботи учнів (створення математичних кросвордів, проєктів, написання мінітворів, малювання ілюстрацій тощо), які активізують емоційно-вольові та інтелектуальні психічні процеси, сприяють формуванню творчих здібностей, математичної компетентності учнів. Подальших досліджень потребує питання підготовки майбутніх учителів початкової школи до розвитку пізнавального інтересу в молодших школярів до математики.

\section{ЛІТЕРАТУРА}

1. Базова навчальна програма для учнів $1-4$ класів загальноосвітніх навчальних закладів. URL: http://www.mon.gov.ua/gr/pr/matemat.doc

2. Богданович М.В., Будна Н. О., Лишенко Г. П. Урок математики в початковій школі : навч. посіб. Тернопіль : Навчальна книга - Богдан, 2004. $208 \mathrm{c}$.

3. Державний стандарт початкової загальної освіти. URL: http://osvita.ua/legislation/Ser_osv/17911/

4. Довгий О. Самостійна робота з математики для майбутніх учителів початкових класів як умова їхнього професійного зростання. Молодь $i$ ринок. 2019. №12 (179). С. 70-74.

5. Коваль Л.В., Скворцова С.О. Методика навчання математики: теорія і практика: Підручник для студентів за спеціальністю 6.010100 "Початкове навчання", освітньокваліфікаційного рівня “бакалавр” 2-ге вид., допов. і переробл. Харків: ЧП “Принт-Лідер”, 2011. 414 с.

6. Навчальна програма 3 математики для початкових класів загальноосвітніх шкіл (1-4 клас), затверджена Колегією Міністерства освіти і науки 4 серпня 2016 року. URL: https://mon.gov.ua $>$ osvita

7. Нова українська школа. URL: https:// mon.gov.ua/storage/app/media/zagalna\%20serednya/ nova-ukrainska-shkola-compressed.pdf

8. Романишин Р. Формування обчислювальних навичок в учнів початкової школи в умовах нетрадиційних технологій навчання. Молодь $i$ ринок. 2020. № 6(185). С. 72-79.

9.Уряд затвердив план року математичної освіти. URL: ww.kmu.gov.ua/npas/pro-zatverdzhennyaplanu-zahodiv-shchodo

10. PISA: математична грамотність / уклад. Т. С. Вакуленко, В. П. Горох, С. В. Ломакович, В. М. Терещенко; перекл. К. С. Шумова. К. : УЦОЯО, 2018. 60 с 
11. OECD (2019). PISA 2018 Results (Volume I): What Students Know and Can Do, PISA, OECD Publishing, Paris, 352 p. Available at: https://doi.org/ 10.1787/5f07c754-en.

\section{REFERENCES}

1. Bazova navchalna prohrama dlia uchniv $1-4$ klasiv zahalnoosvitnikh navchalnykh zakladiv [Basic curriculum for students $1-4$ classes of secondary schools]. Available at: http://www.mon.gov.ua/gr/pr/ matemat.doc [in Ukrainian].

2. Bohdanovych, M.V., Budna, N. O. \& Lyshenko, H. P. (2004). Urok matematyky v pochatkovii shkoli : navch. posib [Mathematics lesson in primary school: textbook. way]. Ternopil, 208 p. [in Ukrainian].

3. Derzhavnyi standart pochatkovoi zahalnoi osvity [State standard of primary general education]. Available at: http://osvita.ua/legislation/Ser_osv/ 17911/ [in Ukrainian].

4. Dovhyi, O. (2019). Samostiina robota $z$ matematyky dlia maibutnikh uchyteliv pochatkovykh klasiv yak umova yikhnoho profesiinoho zrostannia [Independent work on mathematics as a condition of professional growth of future primary school teachers]. Youth \& market. No.12 (179). pp. 7074. [in Ukrainian].

5. Koval, L. V. \& Skvortsova, S. O. (2011). Metodyka navchannia matematyky: teoriia i praktyka: pidruchnyk dlia studentiv za spetsialnistiu 6.010100 "Pochatkove navchannia", osvitno-kvalifikatsiinoho rivnia "bakalavr" [Methods of teaching mathematics: theory and practice: Textbook for students majoring in 6.010100 "Primary Education", educational qualification level "Bachelor"]. Kharkiv, 414 p. [in Ukrainian].

6. Navchalna prohrama $\mathrm{z}$ matematyky dlia pochatkovykh klasiv zahalnoosvitnikh shkil (1-4 klas) [Curriculum in mathematics for primary grades of secondary schools (grades 1-4)]. Available at: https:/ /mon.gov.ua > osvita [in Ukrainian].

7. Nova ukrainska shkola [New Ukrainian school]. Available at: https://mon.gov.ua/storage/app/ media/zagalna\%20serednya/nova-ukrainska-shkolacompressed.pdf [in Ukrainian].

8. Romanyshyn, R.(2020). Formuvannia obchysliuvalnykh navychok v uchniv pochatkovoi shkoly $\mathrm{v}$ umovakh netradytsiinykh tekhnolohii navchannia [Formation of computational skills in primary school students in terms of non-traditional learning technologies]. Youth \& market. No. 6(185). pp. 72-79. [in Ukrainian].

9. Uriad zatverdyv plan roku matematychnoi osvity [The government has approved a plan for the year of mathematics education]. Available at: ww.kmu.gov.ua/npas/pro-zatverdzhennya-planuzahodiv-shchodo [in Ukrainian].

10. PISA: matematychna hramotnist (2018). [PISA: mathematical literacy]. (Ed.). T. S. Vakulenko, V. P. Horokh, S. V. Lomakovych, V. M. Tereshchenko; translation K. Ye. Shumova. Kyiv, 60 p. [in Ukrainian].

11. OECD. (2019). PISA 2018 Results (Volume I): What Students Know and Can Do, PISA, OECD Publishing, Paris, 352 p. Available at: https://doi.org/ 10.1787/5f07c754-en. [in English].

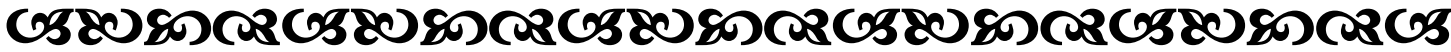

"Ніхто не зможе побудувати для Вас міст, на яқому Ви повинні перетнути потік життя, ніхто, крім Вас самих".

$$
\begin{array}{r}
\text { Фрідріх Нічше } \\
\text { німещький боілособб }
\end{array}
$$

“Відқрити в қожній людині твория, поставити ї̈ на шлях самобутнъої творчої, інтелектуально повноқровної праці - це завдання стає нині першочерговим у практичній роботі".

\section{Василь Сухомлинський уқрайнський педагог}

\section{“Хто рухається вперед у знанні, але відстає в моралі, той сқоріше йде назад, ніж. yneped".

\section{G580}

